\title{
Impact of Corporate Governance on Social and Environmental Information Disclosure of Malaysian Listed Banks: Panel Data Analysis
}

\author{
Sheila $\mathrm{Nu} \mathrm{Nu}$ Htay (Corresponding Author) \\ IIUM Institute of Islamic Banking and Finance \\ International Islamic University Malaysia \\ 205 A, Jalan Damansara, Damansara Heights, 50480 Kuala Lumpur, Malaysia \\ Tel: 60-3-2082-2812 E-mail: sheila@iium.edu.my \\ Hafiz Majdi Ab. Rashid \\ Department of Accounting, Kulliyah of Economics and Management Sciences \\ International Islamic University Malaysia \\ P.O. Box 10, 50728 Kuala Lumpur, Malaysia \\ Tel: 60-3-6196-4699 E-mail: arhafiz@iium.edu.my \\ Mohamad Akhyar Adnan \\ Faculty of Economics, Universitas Muhammadiyah Yogyakarta \\ Jl. Lingkar Selatan, Kasihan Bantul DIY 55183 \\ E-mail: adnan@umy.ac.id \\ Ahamed Kameel Mydin Meera \\ Department of Finance, Kulliyah of Economics and Sciences \\ International Islamic University Malaysia \\ P.O. Box 10, 50728 Kuala Lumpur, Malaysia \\ Tel: 60-3-6196-4754 E-mail: akameel@iium.edu.my
}

Received: July 24, 2011 Accepted: November 28, $2011 \quad$ Published: June 1, 2012

doi:10.5296/ajfa.v4i1.810 URL: http://dx.doi.org/10.5296/ajfa.v4i1.810 


\section{Abstract}

This study investigates the impact of corporate governance on social and environmental information disclosure of Malaysian listed banks by using a panel data analysis. The proxies for good corporate governance are board leadership structure, board composition, board size, director ownership, institutional ownership and block ownership. Social and environmental information disclosure index is developed and content analysis is conducted by cross checking between the social and environmental information disclosed in the annual reports and the disclosure index developed by the researcher. The disclosure score used in this study is weighted disclosure score after considering the opinions of accountants and financial analysts who represent preparers and users of the accounting information respectively. The findings show that smaller board size, higher percentage of independent directors $(1 \%)$ on the board, higher board size (1\%), higher percentage of director ownership, lower institutional and lower block ownership (5\%) have higher information disclosure.

Keywords: Social and environmental reporting, Bank, Corporate governance, Generalized least square, Panel data, Agency theory, Malaysia 


\section{Introduction}

Importance of corporate governance has been highlighted over the world nowadays and it has accused as one of the main causes of crisis. Agency theory and many corporate guidelines suggest having a good corporate governance system for more transparent disclosing information about the corporation. In addition, corporate governance of banks seems to be more important than other industries because the banking sector plays a crucial financial intermediary role in any economy. Poor corporate governance of the banks can drive the market to lose confidence in the ability of a bank to properly manage its assets and liabilities, including deposits, which could in turn trigger a liquidity crisis and then it might lead to economic crisis in a country and pose a systemic risk to the society at large (Garcia-Marco and Robles-Fernandez, 2008). Therefore, it is interested to examine the importance of corporate governance mechanisms in the banking sector.

Information disclosure is an important and efficient means of protecting shareholders and is at the heart of corporate governance. It is also integral to corporate governance, i.e. an important element of corporate governance, since higher disclosure could be able to reduce the information asymmetry, to clarify the conflict of interests between the shareholders and the management, and to make corporate insiders accountable. Among the different types of information disclosed in the annual reports, disclosure on social and environmental information is focused in this study because corporate governance guidelines extends the responsibilities of the board of directors from the shareholders to wider aspect, i.e. stakeholders. Moreover, taking care of society and environment is essential for the long-term sustainability of the firms and corporate social and environmental reporting becomes an important issue nowadays (Pramanik et al., 2008). Cortez and Penacerrada (2010) mention that protecting the society and environment is part of the corporate social responsibility of the corporation and it should be responsible for environmental crisis if it damages the environment. Baxi and Ray (2009), Farid et al. (2009), and Uwalomwa and Uadiale (2011) also state that corporate social and environmental reporting has received attention in recent years as a part of sustainable development process across the world and it becomes very interesting issue for practice and academic area. They further state that the introducing of Global Reporting Initiative in year 2000 has proposed certain guidelines to social, environmental and financial reporting that many companies can follow as guidelines.

However, the social and environmental reporting is still voluntary reporting in most of the developing countries, including Malaysia because they do not have strong policy on social and environmental reporting (Ionescu, 2010). The boards should also consider the interests of the stakeholders and their responsibility should be extended beyond shareholders (Kolk \& Pinkse, 2010). According to Sharifah et al. (2008), in Malaysian context, there are limited studies on the association between corporate governance variables and corporate social reporting except Haniffa and Cooke (2002) and Sharifah et al. (2008). These above stated authors did not focus on financial sector and this study fills up the gap by examining the impact of corporate governance on social and environmental reporting in the financial sector. 
It could be summed that the governance seems to be a heart of the corporation, especially in the banking sector and to have an influential power on information disclosure of the annual reports. Hence, the aim of this paper is to investigate the impact of corporate governance on the social and environmental information disclosure of the banks.

\section{Theoretical Framework and Empirical Studies}

According to Jensen and Meckling (1976), the separation of ownership and control can incur agency cost. One of the best ways to reduce this cost is implementing the good corporate governance (Judge et al., 2003) since it promotes goal congruence among principals and agents (Conyon and Schwalbach, 2000). Cheung and Chan (2004) also describe that information disclosure is one of the tool to monitor the management and it can be used as tool to reduce the cost of capital.

\subsection{Agency Theory and Separate Leadership Structure}

Based on this theory, a clear separation of the responsibilities of the CEO and the chairman of the board and seems to prefer to have separate leadership structure (Jensen and Meckling, 1976; Fama and Jensen, 1983; Jensen, 1993). The combined leadership structure promotes CEO entrenchment by reducing board monitoring effectiveness (Florackis and Ozkan, 2004). Board independence attained by separate leadership is necessary to give pressure on the management in disclosing the more material information about the company, which is in line with the interest of the shareholders. Hence, it could be assumed that the separate leadership structure will lead to better social and environmental disclosure about the companies. The findings of Ho and Wong (2001), Gul and Leung (2004), Lakhal (2005), Byard, Li and Weintrop (2006) and Huafang and Jianguo (2007) are in line with theoretical expectation. This means that there is a positive relationship between separate leadership structure and disclosure. However, Norita and Shamsul Nahar (2004) find that separate leadership structure is not associated with voluntary disclosure.

\subsection{Agency Theory and Board Composition}

Board composition is very important to monitor the managers effectively and reduce the agency cost (Choe and Lee, 2003). Although the executive directors have specialized skills, expertise and valuable knowledge of the firms' operating policies and day-to-day activities, there is a need for the independent directors to contribute the fresh ideas, independence, objectivity and expertise gained from their own fields (Cho and Kim, 2003). Hence, the agency theory recommends the involvement of independent non-executive directors to monitor any self-interested actions by managers and to minimize agency costs (Florackis and Ozkan, 2004; Williams et al., 2006). In addition, it can be derived from the agency theory that higher proportion of the independent non-executive directors on the board will be result in higher disclosure of the material aspects of the company in order to increase the transparency since independent boards will be able to encourage the management to disclose more information. The findings of Chen and Jaggi (2000), Gul and Leung (2004), Byard et al. (2006), and Cheng and Courtenay (2006) and Norita and Shamsul Nahar (2004.) are in line with theoretical expectation. 


\subsection{Agency Theory and Board Size}

Boards with more than seven or eight members are unlikely to be effective (Jensen and Ruback, 1983; Florackis and Ozkan, 2004). They further elaborate that larger boards result in less effective coordination, communication, and decision-making, and are more likely controlled by the CEO. Yoshikawa and Phan (2003) also highlight that larger boards tend to be less cohesive and more difficult to coordinate because there might be a large number of potential interactions and conflicts among the group members and sometimes, larger boards are purposely created by CEOs to disperse the power in the boardroom and reduce the potential for coordinated action by directors, leaving the CEO as the predominant figure. In sum, smaller boards seem to be more conducive to board member participation and thus would result in a positive impact on the monitoring function and the decision-making capability of the board, and independence from the management (Huther, 1997). It is expected that smaller board size should be able to monitor the decision of the management related to the information disclosure. This expectation is supported by the findings of Byard et al. (2006). They study 1279 firms over the years 2000 to 2002 and find that financial disclosure related to forecast information decreases with board size. However, the findings of Lakhal (2005) show that there is an insignificant and weak association between board size and disclosure.

\subsection{Agency Theory and Ownership}

In this study, ownership is looked at from three different perspectives; (a) director ownership, (b) block ownership, and (c) institutional ownership. If directors own shares, the directors as the owners themselves are directly instructing and monitoring the management of the companies (Jensen and Meckling, 1976). Hence, there are likely to be fewer agency problems as compared to the situation where the directors, who are not the owners, supervise the management of the company. It is also supported by Seifert et al. (2005) who discuss agency conflicts. However, in the case of information disclosure, the effect of director ownership on disclosure might be different from that of the block holders and institutional investors. Directors who have substantial amount of share ownership might not want to disclose the information to the outsiders because they can use their discretionary powers to spend firm resources in ways that serve their own interest at the expense of other shareholders and then they might want to conceal fraud and incompetence, if any. Therefore, it could be expected that there is a negative relationship between director ownership and disclosure. Theoretical expectation seems to be supported by Chau and Gray (2002), Eng and Mak (2003), and Leung and Horwitz (2004). Huafang and Jianguo (2007) find that there is no relationship between them. On the contrary, Ballesta and Garcia-Meca (2005) find that higher director ownership provides higher quality of financial reporting. In addition, Norita and Shamsul Nahar (2004) find that executive director ownership has a positive influence to voluntary disclosure level. The reason provided by Ballesta and Garcia-Meca (2005) is that when managers are also the owners, they act in the interest of the firms and thus result in financial statements that are less likely to attract audit qualification. 
With regard to block ownership, David and Kochhar (1996) and Kim and Lee (2003) state that if an individual has a substantial amount of interest in a particular company (usually measured at 5\%), he or she will be more interested in the company and hence the block holders is an important player to have higher disclosure since they have the voting power that could be used as a tool to monitor the agents. From the agency theory, it could be inferred that block holders have the interests in the firms; most likely they might put the pressure on the management to disclose all the material information. Therefore, it could be expected that there is a positive relationship between block holders and disclosure. Chau and Gray (2002), Luo, Courtenay and Hossain (2006)1, Huafang and Jianguo (2007) and Norita and Shamsul Nahar (2004) find that extent of outside block ownership is positively associated with voluntary disclosures and hence their finding is in line with theoretical expectation. However, Eng and Mak (2003) find that block holder ownership is not related to disclosure. The finding of Lakhal (2005) seems not to be in line with theoretical expectation.

Finally, regarding institutional investors, Salleh and Mallin (2002), Le et al. (2006), Langnan, Steven and Weibin (2007) and Ramzi (2008) collectively agree on the important role of institutional shareholders in the monitoring of firms because of the voting power, the potential benefits from their activism, the existence of lesser ability to liquidate the shares without affecting the share price, the fiduciary responsibility towards the ultimate owners, and ability to monitor executives since they are professionals. Institutional ownership seems to be an important player to have higher disclosure since their voting power can be used as a tool to monitor the agents (David and Kochhar, 1996). Therefore, it could be expected that there is a positive relationship between institutional investors and disclosure. The findings of Eng and Mak (2003), and Lakhal (2005) are in line with theoretical expectation. Whereby, Eng and Mak (2003) use government ownership as a proxy for institutional shareholder and Lakhal (2005) use the foreign institutional investor's ownership as the proxy. However, Huafang and Jianguo (2007) find that there is state ownership and legal ownership are not related to disclosure and hence they suggest that the Chinese regulators should gradually encourage multi-ownership.

\section{Development of Hypotheses and Research Design}

\subsection{Development of Hypotheses}

Disclosing the material information of the firms reduces the information asymmetry between the management and the owners, and it will also reduce the agency conflicts between them. According to Patel et al. (2002) and United Nation (2003), disclosure is an integral part of the corporate governance because it shows the extent of how good corporate governance is. Leong (2005) also mentions that disclosure and transparency are partners of good corporate governance. Moreover, Beekes and Brown (2006) study 250 Australian firms rated in the 2002 Horwath Corporate Governance Report and find that better-governed firms do make more informative disclosure. Hence, the researcher is interested to examine whether corporate governance variables could affect the social and environmental information disclosure and the following hypotheses are developed.

\footnotetext{
${ }^{1}$ The existence of outside block ownership significantly decreases managers' ability to limit voluntary disclosure.
} 


\subsubsection{Board Leadership Structure}

There should be a control mechanism that could put pressure on the management to disclose the material information. One of the mechanisms, derived from the agency theory is board independence from the management (Fama \& Jensen, 1983). Corporate governance literature suggests that board independence could be achieved from separate leadership structure. This suggestion is also supported by empirical findings of prior researchers such as Gul and Leung (2004), Lakhal (2005), Byard et al. (2006) and Huafang and Jianguo (2007) since they find that there is a positive relationship between separate leadership structure and disclosure. Therefore, it is expected that separate leadership structure results in higher social and environmental disclosure and the following hypothesis, in an alternative form, is developed.

Ha1: Social and Environmental disclosure is positively related to separate leadership structure.

\subsubsection{Board Composition}

Several researchers based on the agency theory highlight the importance of board independence. It has been well recognized by the corporate governance literature that higher proportion of independent non-executive directors makes the board independent from the management (Choe \& Lee, 2003; Yatim, Kent \& Clarkson, 2006). Furthermore, the findings of prior researchers are in line with the expectation of agency theory, for instance, Chen and Jaggi (2000), Gul and Leung (2004), Byard et al. (2006), and Cheng and Courtenay (2006) and Norita and Shamsul Nahar (2004). They find that higher proportion of independent directors has positive impact on disclosure. Therefore, the researcher expects that higher proportion of independent non-executive directors will contribute to higher disclosure and the following hypothesis, in an alternative form, is developed.

Ha2: Social and environmental disclosure is positively related to proportion of independent non-executive directors on the board.

\subsubsection{Board Size}

As explained earlier, agency theory foresees the problems that could arise due to the separation of ownership and management. In order to reduce the problems between them, the board, as a middle person, should be independent from the management so that the board could be able to monitor the management effectively which is in line with the interest of the shareholders. Several researchers such as Mak and Li (2001), Yoshikawa and Phan (2003), Yatim et al. (2006) and Khanchel (2007) collectively agree that in order for the board to be free from the management, especially from the CEO, and to effectively control the CEO, board size should be small due to difficulties in organizing and coordinating large group of directors. The finding of Byard et al. (2006) is in line with theoretical expectation since their study of 1279 firms over the years 2000 to 2002 shows that analyst forecast accuracy based on the financial disclosure decreases with board size. Therefore, it could be expected that smaller board size will result in better disclosure and the following hypothesis, in an alternative form, is developed. 
Ha3: Social and environmental disclosure is negatively related to board size.

\subsubsection{Ownership}

Corporate governance literature highlights the important role of ownership on the disclosure. If the directors hold the shares, they might not want to disclose all the material information to the outsiders since they would like to channel the benefits of the firms for themselves, not to the outside shareholders and they might conceal some fraud transactions. Hence, it could be expected that higher proportion of director ownership results in lower level of disclosure. The above expectation is supported by Chau and Gray (2002), Eng and Mak (2003), and Leung and Horwitz (2004) since they find that there is a negative relationship between director ownership and disclosure. Therefore, the following hypothesis, in an alternative form, is developed.

Ha4: Social and environmental disclosure is negatively related to director ownership.

On the contrary, in the case of institutional and block ownership, they might put the pressure on the management to disclose all the material information. It is because disclosure is one of the best ways to find out whether the performance of the management meets their expectations, for example, in terms of profitability and risk management. From the agency theory, it also could be derived that since institutional shareholders and block holders have higher proportion of ownership interest, they might be more interested to monitor the firms for better disclosure in order for them to make the economic decisions as well as to discipline poorly performing management (Kang \& Sorensen, 1999; Kim \& Nofsinger, 2004; Birt, Bilson, Smith and Whaley, 2006). This theoretical expectation, i.e. higher institutional or block ownership has a positive impact on disclosure, is supported by the findings of Eng and Mak (2003), and Lakhal (2005), whereby Eng and Mak (2003) use government ownership as a proxy for institutional shareholder and Lakhal (2005) uses the foreign institutional investor's ownership as the proxy. In the case of block ownership, Chau and Gray (2002), Luo et al. (2006), Huafang and Jianguo (2007) and Norita and Shamsul Nahar (2004) find that extent of outside block ownership is positively associated with voluntary disclosures and hence their finding is in line with theoretical expectation. Therefore, the following hypotheses, in an alternative form, are developed. They are:

Ha5: Social and environmental disclosure is positively related to block ownership.

Ha6: Social and environmental disclosure is positively related to institutional ownership.

\subsection{Research Design}

\subsubsection{Variables and Empirical Model}

Dependent Variable

Weighted social and environmental information disclosure score is used as a dependent variable and questionnaire (Refer to Appendix) is developed to obtain views on the importance of each disclosure item from financial analysts and accountants. Before the actual questionnaire is sent, pilot test has been conducted and the findings show that alpha value is 
0.94 and so it has been concluded that the questionnaire is reliable. In addition, pilot test results show that the overall mean score of comprehensiveness of the questionnaire is 4.05, understandability of the questions is 4.10 and understandability of the instruction is 4.62 . Therefore, it can be concluded that the pilot test questionnaire is good enough to be used as an actual questionnaire. List of social and environmental disclosure items and pilot test results can be referred to Table 1 and Table 2 respectively.

Table 1: List of Social and Environmental Information Disclosure

\begin{tabular}{|l|}
\hline Share option schemes-Policy (Quantitative) \\
Share option schemes-Policy (Qualitative) \\
Profit sharing schemes-Policy (Quantitative) \\
Profit sharing schemes-Policy (Qualitative) \\
Amount spent on training \\
Policy on training \\
Welfare information \\
Recruitment policy \\
Charitable donations (Quantitative) \\
Charitable donations (Qualitative) \\
Community programs (Quantitative) \\
Community programs (Qualitative) \\
Environmental protection policy (Quantitative) \\
Environmental protection policy (Qualitative) \\
Effect on environment (Quantitative) \\
Effect on environment Qualitative) \\
\hline
\end{tabular}

Table 2. Mean Score for Comprehensiveness and Understandability of the Questions and the Instruction (Pilot Test)

\begin{tabular}{|l|l|c|c|c|}
\cline { 3 - 5 } \multicolumn{2}{|c|}{ No. } & \multicolumn{1}{|c|}{ Description } & \multicolumn{3}{c|}{ Accountants } & $\begin{array}{c}\text { Financial } \\
\text { Analysts }\end{array}$ & Overall \\
\hline 1 & $\begin{array}{l}\text { The questionnaire comprehensively } \\
\text { covers the important disclosure items } \\
\text { of the annual reports. }\end{array}$ & 4.22 & 3.92 & 4.05 \\
\hline 2 & $\begin{array}{l}\text { The contents of the questionnaire are } \\
\text { easy and simple for the respondents to } \\
\text { understand. }\end{array}$ & 4.22 & 4.00 & 4.10 \\
\hline 3 & $\begin{array}{l}\text { The instructions to answer the } \\
\text { questionnaire are clear. }\end{array}$ & 4.78 & 4.50 & 4.62 \\
\hline
\end{tabular}

The annual reports of the sample companies are checked against disclosure index developed by the researcher. The researcher uses dichotomous score, i.e. one is given if the company 
discloses the information, and zero for otherwise. Since the annual reports are checked against the disclosure index to provide the disclosure score, during this process, some of the disclosures in the annual reports are not clear for the researcher to decide whether some parts of annual report disclosure represent the items from the disclosure index. Hence, for these confusing items, questionnaire is constructed and sent to the ten accountants and six financial analysts in order to seek their opinions on whether these confusing disclosures in the annual reports represent the items in the disclosure check list. It is found out that there is no significant difference between the score provided by the researcher and the answers provided by the selected accountants and financial analysts. Finally, the weight for each disclosure item is calculated by the mean score of each disclosure item provided by the accountants and financial analysts.

\section{Independent Variables}

There are six independent variables, which comprise of three structural measures of corporate governance (i.e. board leadership structure, board composition and board size) and three measures of ownership structure (i.e. director ownership, institutional ownership, and block ownership). Finally, the empirical model of the study also includes two control variables related to firm-specific characteristics (i.e. firm size and leverage) because most of the prior researchers such as Ho and Wong (2005), Chau and Gray (2002), Haniffa and Cooke (2002), Hyytinen and Pajarinen (2005), Eng and Mak (2003), Leung and Horwitz (2004), Ballesta and Garcia-Meca (2005), Lakhal (2005), Luo et al. (2006), Huafang and Jianguo (2007) and Norita and Shamsul Nahar (2004) have used the above two variables as control variables in examining the relationship between corporate governance variables and disclosures. Firm size is controlled because larger and more profitable firms tend to have higher disclosure because they are closely followed by financial intermediaries and need more comprehensive disclosure to minimize the political costs of noncompliance (Aksu \& Kosedag, 2006). For instance, Kee and Pillay (2003) find that firm size is significantly associated with voluntary disclosure level. In addition, leverage is used as a control variable because in highly leveraged firms, there is a high demand for and supply of information required by the lenders (Aksu \& Kosedag, 2006). According to the corporate governance literature, firm size is commonly measured by total assets and leverage is measured by the ratio of total debt to equity. The complete empirical model is as follow.

Yit $=\beta$ o $+\beta 1 \times 1$ it $+\beta 2 \times 2$ it $-\beta 3 \times 3$ it $-\beta 4 \times 4$ it $+\beta 5 \times 5$ it $+\beta 6 \times 6$ it $+\beta 7 \times 7$ it $+\beta 8 \times 8$ it $+\mu$ it

Where,

$\mathrm{i}=1,2,3,4,5,6,7,8,9,10,11,12$

$\mathrm{t}=1,2,3,4,5,6,7,8,9,10$

$\mathrm{Y}=$ Weighted social and environmental information disclosure score

$\mathrm{x} 1=$ Board leadership structure (BLS)

x2= Proportion of independent non-executive directors on the board (INE_BZ) 
$\mathrm{x} 3=$ Board size $(\mathrm{BZ})$

$\mathrm{x} 4=$ Proportion of director ownership (DOWN)

$\mathrm{x} 5=$ Proportion of institutional ownership (IOWN)

$\mathrm{x} 6=$ Proportion of block ownership $(\mathrm{BOWN})$

$\mathrm{x} 7=\log$ of total assets (TA)

$\mathrm{x} 8=$ Leverage $\left(\mathrm{TD} \_\mathrm{TE}\right)$

$\mu=$ Error term

\subsubsection{Sample selection and Statistical Methods}

Samples include the twelve listed companies whose main activity is banking from 1996 until 2005. The total number of observations is 120 observations. However, some of the observations need to be dropped due to unavailability of data and some companies were not classified as banks in all the ten years' period. It left the final observations to 108 observations. There were significant events incurred during the 10-years span of the sample period. First, the introduction of MCCG (2007) promotes better transparency of information disclosure. Secondly, the financial crisis incurred towards the end of the 1990s. Thirdly, CSR framework is introduced by Bursa Malaysia in 2006 and this framework lays down regulation on disclosure of social and environment information. Therefore, the period before 2006 will be better in capturing the nature of purely voluntary environment for social and environmental disclosure. Data were collected either from the annual reports of the companies or from Bloomberg. The main statistical method used in this study is panel data analysis (generalized least square method). Generalized least square method is used because the sample data are not normally distributed and the data have, either, heteroskedasticity problem, autocorrelation problem or both. According to Gujarati (2003), using generalized least square method will overcome all these problems.

\section{Profile of the Respondents}

The background information about the respondents includes gender, educational background, employment category, age and working experience of the respondents (Refer to Table 3). Overall, both male and female respondents seem to be equally distributed since forty nine percent of the respondents are male and fifty one percent of them are female. Regarding educational background, the majority of them are bachelor degree holders, and the balances are professional certificate holders. Since fifty seven percent of the respondents are from the audit firms and forty three percent of them are from the non-audit firms, the opinion seems not to be too much influenced by one particular group although majority of the respondents are accountants. The age range of the majority is between twenty and twenty-nine, followed by the age range between thirty and thirty-nine. In terms of working experience, majority of the respondents, i.e. forty three percent, are below three years in the current profession and twenty three percent of them have working experience between three to seven years. 
Table 3. Profile of Respondents

\begin{tabular}{|c|c|c|c|c|c|c|}
\hline & \multicolumn{2}{|c|}{ Accountants } & \multicolumn{2}{|c|}{ Financial analysts } & \multicolumn{2}{|c|}{ Overall } \\
\hline & Frequency & Percentage & Frequency & Percentage & Frequency & Percentage \\
\hline \multicolumn{7}{|l|}{ Gender } \\
\hline Male & 52 & 39.69 & 37.00 & 72.55 & 89.00 & 48.90 \\
\hline Female & 79 & 60.31 & 14.00 & 27.45 & 93.00 & 51.10 \\
\hline Total & 131 & 100.00 & 51.00 & 100.00 & 182.00 & 100.00 \\
\hline \multicolumn{7}{|l|}{ Educational background } \\
\hline Bachelor degree & 74 & 56.92 & 25.00 & 50.00 & 99.00 & 55.00 \\
\hline Master & 6 & 4.62 & 19.00 & 38.00 & 25.00 & 13.89 \\
\hline Ph.D & & & 1.00 & 2.00 & 1.00 & 0.56 \\
\hline $\begin{array}{l}\text { Professional qualification } \\
\text { (ACCA, CIMA, CFA, etc) }\end{array}$ & 50 & 38.46 & 5.00 & 10.00 & 55.00 & 30.56 \\
\hline Total & 130 & 100.00 & 50.00 & 100.00 & 180.00 & 100.00 \\
\hline \multicolumn{7}{|l|}{ Employment category } \\
\hline Audit firm & 103 & 78.63 & 1.00 & 1.96 & 104.00 & 57.14 \\
\hline Non-audit firm & 28 & 21.37 & 50.00 & 98.04 & 78.00 & 42.86 \\
\hline Total & 131 & 100.00 & 51.00 & 100.00 & 182.00 & 100.00 \\
\hline \multicolumn{7}{|l|}{ Age range } \\
\hline \multicolumn{7}{|l|}{ Below 20} \\
\hline $20-29$ & 63 & 48.09 & 11.00 & 21.57 & 74.00 & 40.66 \\
\hline $30-39$ & 35 & 26.72 & 22.00 & 43.14 & 57.00 & 31.32 \\
\hline $40-49$ & 27 & 20.61 & 14.00 & 27.45 & 41.00 & 22.53 \\
\hline $50-59$ & 4 & 3.05 & 4.00 & 7.84 & 8.00 & 4.40 \\
\hline 60 and above & 2 & 1.53 & & & 2.00 & 1.10 \\
\hline Total & 131 & 100.00 & 51.00 & 100.00 & 182.00 & 100.00 \\
\hline \multicolumn{7}{|l|}{$\begin{array}{l}\text { Working experience } \\
\text { with current profession }\end{array}$} \\
\hline Below 3 years & 63.00 & 48.09 & 15.00 & 29.41 & 78.00 & 42.86 \\
\hline $3-7$ & 29.00 & 22.14 & 13.00 & 25.49 & 42.00 & 23.08 \\
\hline $8-12$ & 16.00 & 12.21 & 10.00 & 19.61 & 26.00 & 14.29 \\
\hline $13-17$ & 15.00 & 11.45 & 7.00 & 13.73 & 22.00 & 12.09 \\
\hline $18-22$ & 2.00 & 1.53 & 3.00 & 5.88 & 5.00 & 2.75 \\
\hline $23-27$ & 2.00 & 1.53 & 3.00 & 5.88 & 5.00 & 2.75 \\
\hline Above 27 & 4.00 & 3.05 & & & 4.00 & 2.20 \\
\hline Total & 131.00 & 100.00 & 51.00 & 100.00 & 182.00 & 100.00 \\
\hline \multicolumn{7}{|l|}{ Additional information } \\
\hline Masters & & & 1.00 & 1.96 & 1.00 & 0.55 \\
\hline $\begin{array}{l}\text { Professional qualifications } \\
\text { (ACCA, CIMA, CFA, etc) }\end{array}$ & 15.00 & 11.45 & 7.00 & 13.73 & 22.00 & 12.09 \\
\hline
\end{tabular}




\section{Response Rate and Reliability Test Results}

For accountants, total of three hundred and twenty seven questionnaires (i.e. two hundred sixty nine questionnaires to audit firms and fifty eight questionnaires to commercial firms) are distributed to fifty-two audit firms and fourteen commercial firms. The questionnaires are distributed and collected either by hand or mail. Out of three hundred and twenty seven questionnaires dispatched one hundred and thirty one accountants response and hence the response rate is forty percent.

In the case of financial analysts, eighty-three questionnaires are sent to eighteen equity broker companies. All the questionnaires are sent by hand. Only fifty-one financial analysts respond to the questionnaires. Hence the response rate is sixty three percent. Of the fifty-one respondents, forty-three questionnaires are collected by hand. Due to late responses, envelopes are left for the financial analysts to reply through mail. Later on, one questionnaire is collected by hand, six questionnaires are received by mail, and one is received through e-mail.

The weighted social and environmental information disclosure score used in this study is based on the opinions of one hundred and thirty one accountants and fifty-one financial analysts. There is no non-response bias from the questionnaire received from the accountants and financial analysts based on T statistics and Mann-Whitney U test (Refer to Table 4). The reliability test results show that the alpha value is 0.89 and so the weighted social and environmental disclosure score used in this study is reliable.

Table 4. Reliability Test Results: Actual Respondents

\begin{tabular}{|l|c|c|c|}
\cline { 2 - 4 } \multicolumn{1}{c|}{} & \multicolumn{3}{c|}{ Alpha } \\
\cline { 2 - 4 } \multicolumn{1}{c|}{} & Accountants & $\begin{array}{c}\text { Financial } \\
\text { analysts }\end{array}$ & Overall \\
\hline $\begin{array}{l}\text { Disclosure on Social, } \\
\text { Environmental and Value Added } \\
\text { Information }\end{array}$ & 0.88 & 0.90 & 0.89 \\
\hline
\end{tabular}

\section{Discussion on the Results}

Based on the descriptive statistics results (refer to Table 5), board leadership structure with mean value (0.81) shows that a majority of the companies have separate leadership structure although the minimum value (zero) shows that there are companies, which have combined leadership structure. Similar to the recommendation of the MCCG (2001), the sample mean value (0.36) shows that ratio of independent directors is slightly more than one third of the total number of the directors. The mean value (8.23) of board size shows existence of a quite a reasonable board size, e.g. Jensen and Ruback (1983) suggest that a board size of not more than 7 or 8 members is considered reasonable in ensuring effectiveness. For ownership, the mean values of director ownership and institutional ownership are 0.02 and 0.17 respectively. The ownership of shares by directors can be considered very low where, on average, only 2 
percent of shares owned by the directors. On the other hand, institutional investors, on average, owned 17 percent of shares, which could still be considered low although it is significantly higher than the ownership by the directors. In the case of block ownership, its mean value $(0.53)$ shows that large shareholders own the significant portion of the shares. The mean value of weighted social and environmental disclosure score is 176.23. As for the firm-specific characteristics, the sample companies have the means values of RM45992.19 millions for total assets and 344.73 for the ratio of total debt to total equity. In addition, Table 6 shows the correlation among the independent variables.

Table 5. Descriptive statistics: Independent, dependent and control variables

\begin{tabular}{|c|c|c|c|c|c|c|c|}
\hline & Mean & Std. Dev. & Min & Median & $\operatorname{Max}$ & Skewness & Kurtosis \\
\hline \multicolumn{8}{|c|}{ Independent variables } \\
\hline \multicolumn{8}{|l|}{ CG variables } \\
\hline BLS & 0.81 & 0.40 & 0.00 & 1.00 & 1.00 & -1.57 & 0.46 \\
\hline INE_BZ & 0.36 & 0.18 & 0.10 & 0.33 & 0.83 & 0.68 & -0.49 \\
\hline $\mathrm{BZ}$ & 8.23 & 2.34 & 4.00 & 8.00 & 14.00 & 0.33 & -0.62 \\
\hline \multicolumn{8}{|l|}{$\begin{array}{l}\text { (b) Ownership } \\
\text { variables }\end{array}$} \\
\hline DOWN & 0.02 & 0.05 & 0.00 & 0.00 & 0.25 & 3.26 & 10.40 \\
\hline IOWN & 0.17 & 0.18 & 0.00 & 0.09 & 0.64 & 1.00 & -0.53 \\
\hline BOWN & 0.53 & 0.21 & 0.00 & 0.58 & 1.00 & -0.81 & 0.04 \\
\hline \multicolumn{8}{|c|}{ Dependent variable } \\
\hline $\begin{array}{l}\text { Weighted } \\
\text { Social and } \\
\text { environmental } \\
\text { disclosure } \\
\text { score }\end{array}$ & 176.23 & 61.67 & 78.93 & 182.23 & 297.65 & 0.12 & -0.80 \\
\hline \multicolumn{8}{|c|}{ Control variables } \\
\hline $\mathrm{TA}$ & 45992.19 & 40245.92 & 1120.36 & 33326.95 & 191895.30 & 1.54 & 2.28 \\
\hline TD_TE & 344.73 & 331.14 & 14.03 & 223.80 & 1442.26 & 1.60 & 1.89 \\
\hline
\end{tabular}




\section{Macrothink}

Table 6. Correlation between variables

\begin{tabular}{|l|c|c|c|c|c|c|c|c|c|c|}
\hline & BLS & INE_BZ & BZ & DOWN & IOWN & BOWN & TA & TD_TE & $\begin{array}{l}\text { GDP } \\
\text { RATE }\end{array}$ & $\begin{array}{l}\text { DUM_ } \\
\text { CRISIS }\end{array}$ \\
\hline BLS & 1.00 & & & & & & & & & \\
\hline INE_BZ & 0.12 & 1.00 & & & & & & & & \\
\hline BZ & -0.39 & -0.20 & 1.00 & & & & & & & \\
\hline DOWN & -0.42 & -0.12 & 0.41 & 1.00 & & & & & & \\
\hline IOWN & -0.05 & -0.26 & -0.03 & -0.10 & 1.00 & & & & & \\
\hline BOWN & -0.08 & -0.36 & -0.02 & 0.12 & 0.34 & 1.00 & & & & \\
\hline TA & -0.04 & 0.11 & 0.43 & -0.08 & -0.03 & -0.05 & 1.00 & & & \\
\hline TD_TE & -0.37 & -0.26 & 0.02 & -0.02 & 0.15 & 0.14 & 0.32 & 1.00 & & \\
\hline GDP RATE & -0.01 & 0.12 & -0.10 & -0.08 & -0.01 & -0.06 & 0.04 & 0.01 & 1.00 & \\
\hline DUM_CRISIS & -0.07 & -0.18 & -0.07 & 0.14 & -0.14 & 0.17 & -0.15 & -0.03 & -0.24 & 1.00 \\
\hline Note: The figures provided above are the correlation coefficients and none are significant at $5 \%$ level. & & \\
\hline
\end{tabular}

The following Table 7 shows the results on disclosure of social and environmental information. INE_BZ (at 5\% Sig. level), DOWN and IOWN are in line with hypothesis while BLS, BZ (at 1\% Sig. level), and BOWN (at 1\% Sig. level) are not in line with hypothesis. Thus, it can be concluded that higher INE_BZ, larger BZ, lower BOWN have higher social and environmental information disclosure. Regarding the social and environmental disclosure, the reasons for the rest of the variables not being in line with hypothesis might be (a) the information disclosure on social and environmental information seems to be new compared to the traditional financial information and (b) measuring the level of disclosure quality of social and environmental matters is subjective.

\footnotetext{
${ }^{2}$ DUM_CRISIS refers to economic crisis dummy.
} 
Table 7. GLS Results of Social and Environmental Information Disclosure

\begin{tabular}{|c|c|c|c|}
\hline & Coefficient & Z_value & $\mathrm{P}$ value \\
\hline \multicolumn{4}{|l|}{$\begin{array}{c}\text { Independent } \\
\text { variables }\end{array}$} \\
\hline BLS & -1.26 & -0.72 & 0.47 \\
\hline INE_BZ & 4.11 & $2.1 * *$ & 0.04 \\
\hline $\mathrm{BZ}$ & 0.70 & $3.79 *$ & 0.00 \\
\hline DOWN & -3.94 & -0.41 & 0.68 \\
\hline IOWN & 0.10 & 0.04 & 0.97 \\
\hline BOWN & -7.26 & $-3.99 *$ & 0.00 \\
\hline \multicolumn{4}{|l|}{ Control variables } \\
\hline LNTA & 3.15 & 6.15* & 0.00 \\
\hline TD_TE & 0.00 & $-2.62 *$ & 0.01 \\
\hline CONS & -24.89 & $-5.42 *$ & 0.00 \\
\hline $\begin{array}{l}\text { Chi-Sq. } \\
\text { P value }\end{array}$ & & & $\begin{array}{c}1274.26 * \\
0.00\end{array}$ \\
\hline $\begin{array}{l}\text { Heteroskedastic } \\
\text { (LR Test) }\end{array}$ & $\begin{array}{l}\text { LR Chi }^{2} \\
\text { P value }\end{array}$ & & $\begin{array}{c}49.12 * \\
0.00 \\
\end{array}$ \\
\hline $\begin{array}{l}\text { Autocorrelation } \\
\text { (Wooldridge Test) }\end{array}$ & $\begin{array}{l}\text { F statistics } \\
\text { P value }\end{array}$ & & $\begin{array}{l}2.32 \\
0.16 \\
\end{array}$ \\
\hline $\begin{array}{l}* \text { Significant at } 1 \% \\
* * \text { Significant at } 5 \%\end{array}$ & & & \\
\hline
\end{tabular}

Regarding board size, descriptively, the board size of the sample companies are relatively small compared to the average board size in UK and US. According to Allen and Gale (2001), in U.S. and U.K., the BZ is around 10 to 15 people. Furthermore, Jensen (1993) in Rashidah and Fazilah (2006) mentions that the limit of board size is around eight directors as any greater number will interfere with group dynamics and inhibit board performance. Coleman et al., (2007) highlight that a range of optimal board size of eight to eleven is feasible for good performance. The descriptive statistics results of this study show that on the average, the board size of the sample companies is around 8. Based on the average board size of the sample companies, it could be summed that in general, the companies have the optimal board size and consequently, it becomes difficult to examine the significant and consistent impact of board size on the dependent variables. Apart from that, according to the resource dependence theory, larger board size seems to be better since a large number of overall connections with organizations and directors outside the firm provide more sources of information for the director and a level of environmental awareness not readily available to the management (Muth and Donaldson, 1998). Hence, in the Malaysian context, the implication of resource dependence theory should be considered since the companies 
involved in the banking sectors might need more directors due to the risky nature of business activities.

Regarding block ownership, the findings of Lakhal (2005) and Salim (2007) are similar with this research results. Lakhal (2005) finds that there is a negative association between voluntary earnings disclosure and ownership concentration. It might be due to the following facts. First, on the average, 53 percentage of ownership belongs to the block ownership and hence, it seems that block ownership has substantial ownership interest which motivates them to monitor the management. However, since block holders may have the substantial voting power, they might choose family members or trust persons to be the board members in order to know about the financial performance of the banks, not social and environmental performance. Hence, they have ensured the performance of the management and they might not be motivated to put pressure to disclose more information about the society and environment. The prior researchers such as Ho and Wong (2001), Chau and Gray (2002) and Haniffa and Cooke (2002) also find that the level of information disclosure is likely to be less in insider or family-controlled companies. Secondly, since they have the controlling rights, they may be in a better position to expropriate company assets and exploit the interest of the minority (Leng and Shazaili, 2005; Zulkarnain, 2007). Due to that they might discourage the higher disclosure. Finally, Santema et al. (2005), Talha, Sallehhuddin and Mohammad (2006) and $\mathrm{Lu}$ et al. (2007) mention the disadvantage of information disclosure. According to Santema et al. (2005), general disclosure costs consist of the cost of gathering, processing and auditing and disseminating the information, as well as possible litigation costs and cost that might create competitive disadvantage. Talha et al. (2006) who study the segmental reporting practice in Malaysia mention that the cost of disclosure includes competitor pressure, political pressure and customer pressure. $\mathrm{Lu}$ et al. (2007) highlight that information disclosure may reduce shareholder value by revealing valuable information to competitors or by increasing legal costs for the firm even though they recognize the advantages of disclosure such as increase in institutional interest and liquidity of the firms and consequently there will be lower cost of capital and public relation benefits (Santema et al., 2005).

\section{Conclusion, Limitation and Area for Future Research}

The findings of this research show that smaller board size, higher percentage of independent directors $(1 \%)$ on the board, higher board size (1\%), higher percentage of director ownership, lower institutional and lower block ownership (5\%) have higher information disclosure. The first limitation of this study is due to small sample size since this study focuses on twelve companies whose main business activity is banking business and they are listed on Bursa Malaysia. Second limitation is the exclusion of foreign banks due to the unavailability of the data. This study focuses on the main corporate governance variables, i.e. board leadership structure, board composition, board size and the ownership variables, i.e. director ownership, institutional ownership and block ownership. Hence, future research might be extended by observing other corporate governance variables such as board meeting frequency, which represents board activeness and the independence of audit committee, which represents its effectiveness. This study focuses on the ownership of institutional ownership and block 
ownership but does not distinguish among the different types of institutional ownership such as foreign, local, government and etc. Hence, future research might consider it.

\section{References}

Aksu, M. \& Kosedag, A. (2006). Transparency and disclosure scores and their determinants in the Istanbul stock exchange. Journal Compilation, 14 (4), 277-295.

Allen, F. \& Gale, D. (2001). Comparative financial systems: A survey, available at: http://www.econ.nyu.edu/user/galed/papers/paper01-04-01.pdf (accessed 29 April 2008).

Alok, K., Nikhil, C., \& Bhagaban, D. (2008). Corporate Environmental Reporting: An Emerging Issues in the Corporate world, International Journal of Business and Management, Vol.3 No. 12.

Ballesta, J.P.S., \& Garcia-Meca, E. (2005). Audit qualifications and corporate governance in Spanish listed firms, Managerial Auditing Journal, Vol. 20 No.7, pp. 725-738. http://dx.doi.org/10.1108/02686900510611258

Baxi, C.V. \& Ray, R.S. (2009). Corporate Social and Environmental Disclosures and Reporting, The Indian Journal of Industrial Relations, Vol. 44 No.3.

Beekes, W. \& Brown, P. (2006). Do better-governed Australian firms make more informative disclosures? Journal of Business Finance and Accounting, Vol. 33 No. 3, pp. 422-450. http://dx.doi.org/10.1111/j.1468-5957.2006.00614.x

Birt, J.L., Bilson, C.M., Smith, T. \& Whaley, R.E. (2006). Ownership, competition and financial disclosure. Australian Journal of Management, 31 (2), 235-263. http://dx.doi.org/10.1177/031289620603100204

Byard, D., Li, Y. \& Weintrop, J. (2006). Corporate governance and the quality of financial analysts' information, Journal of Accounting and Public Policy, Vol.25, pp. 609-625. http://dx.doi.org/10.1016/j.jaccpubpol.2006.07.003

Chau, G.K. \& Gray, S.J. (2002). Ownership structure and corporate voluntary disclosure in Hong Kong and Singapore, The International Journal of Accounting, Vol. 37, pp. 247-265. http://dx.doi.org/10.1016/S0020-7063(02)00153-X

Chen, C.J.P. \& Jaggi, B. (2000). Association between independnet non-executive directors, family control and financial disclosures in Hong Kong, Journal of Accounting and Public Policy, Vol. 19, pp. 285-310. http://dx.doi.org/10.1016/S0278-4254(00)00015-6

Cheng, E.C.M. \& Courtenay, S.M. (2006). Board composition, regulatory regime and voluntary disclosure, The International Journal of Accounting, Vol.41, pp. 262-289. http://dx.doi.org/10.1016/j.intacc.2006.07.001

Cheung, S.Y.L. \& Chan, B.Y. (2004). Corporate governance in Asia, Asia-Pacific Development Journal, Vol. 11 No.2, pp. 1-31. 
Cho, D.S. \& Kim, J. (2003). Determinants in introduction of outside directors in Korean companies, Journal of International and Area Studies, Vol 10, No.1, pp. 1-20.

Choe, H. \& Lee, B.S. (2003). Korean bank governance reform after the Asian financial crisis, Pacific-Basin Finance Journal, Vol. 11, pp. 483-508. http://dx.doi.org/10.1016/S0927-538X(03)00051-9

Coleman, A.K., Adjasi, C.K.D. \& Abor, J. (2007). Corporate governance and firm performance: Evidence from Ghanaian listed companies, Corporate Ownership and Control, Vol. 4 No.2), pp. 123-132.

Conyon, M.J. \& Schwalbach, J. (2000). Executive compensation: Evidence from the UK and Germany, Long Range Planning, Vol. 33, pp. 504-526. http://dx.doi.org/10.1016/S0024-6301(00)00052-2

Cortez, M.A.A. \& Penacerrada, N.T. (2010). Is it Beneficial to Incur Environmental Cost? A Case Study of Toyota Motors Corporation, Japan, Journal of International Business Research, Vol. 9 No. 2.

David, P. \& Kochhar. (1996). Barriers to effective corporate governance by institutional investors: Implications for theory and practice, European Management Journal, Vol.14 No.5, pp. 457-466. http://dx.doi.org/10.1016/0263-2373(96)00039-4

Eng, L.L. \& Mak, Y.T. (2003). Corporate governance and voluntary disclosure, Journal of Accounting and Public Policy, Vol. 22, pp. 325-345. http://dx.doi.org/10.1016/S0278-4254(03)00037-1

Fama, E.F. \& Jensen, M. (1983). Separation of ownership and control, Journal of Law and Economics, Vol.26, pp. 301-325. http://dx.doi.org/10.1086/467037

Farid, A., Azlan, A., Yusserie, Z. (2009), Revisiting the Practices of Corporate Social and Environmental Disclosure in Bangladesh, Corporate social Responsibility and Environmental Management, available at: http://www.interscience.wiley.com

Finance Committee on Corporate Governance. (2001). Malaysian Code on Corporate Governance, Kuala Lumpur: Printmate Sdn. Bhd.

Florackis, C. \& Ozkan, A. (2004). Agency costs and corporate governance mechanisms: Evidence for UK firms, available at: http://www.soc.uoc.gr/asset/accepted_papers/paper87.pdf, (accessed 16 May 2008).

Garcia-Marco, T. \& Robles-Fernandex, M.D. (2008). Risk-taking behaviour and ownership in the banking industry: The Spanish evidence, Journal of Economics and Business, Vol. 60, pp. 332-354. http://dx.doi.org/10.1016/j.jeconbus.2007.04.008

Gujarati, D.N. (2003). Basic econometrics (4th edn.). Singapore: McGraw-Hill.

Gul, F.A. \& Leung, S. (2004). Board leadership, outside directors' expertise and voluntary corporate disclosure, Journal of Accounting and Public Policy, Vol. 23, pp. 351-379. http://dx.doi.org/10.1016/j.jaccpubpol.2004.07.001 
Haniffa, R.M. \& Cooke, T.E. (2002). Culture, corporate governance and disclosure in Malaysian corporations, ABACUS, Vol. 38 No.3, pp. 317-349. http://dx.doi.org/10.1111/1467-6281.00112

Ho, S.S.M. \& Wong, K.S. (2001). A study of the relationship between corporate governance structures and the extent of voluntary disclosure, Journal of International Accounting, Vol. 10, pp. 139-156.

Huafang, X. \& Jianguo, Y. (2007). Ownership structure, board composition and corporate voluntary disclosure: Evidence from listed companies in China, Managerial Auditing Journal, Vol. 22 No.6, pp. 604-619. http://dx.doi.org/10.1108/02686900710759406

Huther, J. (1997). An empirical test of the effect of board size on firm efficiency, Economics Letter, 54, pp. 259-264. http://dx.doi.org/10.1016/S0165-1765(97)00035-9

Hyytinen, A. \& Pajarinen, M. (2005). External finance, firm growth and the benefits of information disclosure: Evidence from Finland. European Journal of Law and Economics, 19(1), 69-93. http://dx.doi.org/10.1007/s10657-005-5276-3

Ionescu, L., (2010). The Role of Financial Globalization in the Changing Governance Practices, Economics Management and Financial Markets, Vol. 5 No. 2, pp.279-284.

Jensen, M.C. \& Meckling, W.H. (1976). Theory of the firm: Managerial behavior, agency costs and ownership structure, Journal of Financial Economics, Vol. 3 No. 4, 305-360. http://dx.doi.org/10.1016/0304-405X(76)90026-X

Jensen, M.C. \& Ruback, R. (1983). The market for corporate control: The scientific evidence, Journal of Financial Economics, Vol. 11, pp. 5-50. http://dx.doi.org/10.1016/0304-405X(83)90004-1

Jensen, M.C. (1993). Presidential address: The modern industrial evolution, exit and the failure of internal control system, Journal of Finance, Vol. 48, pp. 831-880. http://dx.doi.org/10.2307/2329018

Judge, W.Q., Naoumova, I. \& Koutzevol, N. (2003). Corporate governance and firm performance in Russia: an empirical study, Journal of World Business, Vol 38, pp. 385-396. http://dx.doi.org/10.1016/j.jwb.2003.08.023

Kang, D.L. \& Sorensen, A.B. (1999). Ownership organization and firm performance. Annual Review, 25, 121-44. http://dx.doi.org/10.1146/annurev.soc.25.1.121

Kee, P.L. \& Pillay, S.S. (2003, April). Firm-specific determinants of voluntary disclosure level in the annual reports of Malaysian companies. Paper presented at Malaysian Finance Association 5th Annual Symposium, Selangor, Malaysia.

Khanchel, I. (2007). Corporate governance: Measurement and determinant analysis. $\begin{array}{lllll}\text { Managerial } & \text { Auditing } & \text { Journal, } & 22 & \text { (8), }\end{array}$ http://dx.doi.org/10.1108/02686900710819625 
Kim, B. \& Lee, I. (2003). Agency problems and performance of Korean companies during the Asian financial crisis: Chaebol vs. non-chaebol firms, Pacific-Basin Finance Journal, Vol. 11, pp. 327-348. http://dx.doi.org/10.1016/S0927-538X(03)00027-1

Kim, K.A. \& Nofsinger, J.R. (2004). Corporate governance. New Jersey: Pearson Prentice Hall.

Kolk, A. \& Pinkse, J (2010). The Integration of Corporate Governance in Corporate Social Responsibility Disclosures, Corporate Social Responsibility and Environmental Management, Vol.17 pp. 15-26.

Lakhal, F. (2005). Voluntary earnings disclosures and corporate governance: Evidence from France, Review of Accounting and Finance, Vol. 4 No. 3, pp. 64-85. http://dx.doi.org/10.1108/eb043431

Langnan Chen, Steven Li, \& Weibin Lin. (2007). Corporate governance and corporate performance: some evidence from newly listed firms on Chinese stock markets, International Journal of Accounting, Auditing and Performance Evaluation 2007, Vol. 4 No.2, pp. 183 197. http://dx.doi.org/10.1504/IJAAPE.2007.015233

Le, S.A., Walters, B. \& Kroll, M. (2006). The moderating effects of external monitors on the relationship between R and D spending and firm performance, Journal of Business Research, Vol. 59, pp. 278-287. http://dx.doi.org/10.1016/j.jbusres.2005.04.003

Leng, A.C.A. \& Shazaili, A. M. (2005). Can good corporate governance practices contribute to firms' financial performance?-Evidence from Malaysian companies, Int. J. Business Governance and Ethics, Vol. 1 No.4, pp. 350-362. http://dx.doi.org/10.1504/IJBGE.2005.006717

Leong, J. (2005). Corporate risk disclosure and transparency: What risks should organization disclosure and how?, paper presented at Asia Corporate Governance Conference 2005: Managing Corporate Responsibility and Crisis through Fairness, Transparency and Accountability, Kuala Lumpur, Malaysia.

Leung, S. \& Horwitz, B. (2004). Director ownership and voluntary segment disclosure: Hong Kong experience, Journal of International Financial Management and Accounting, Vol.15 No.3, pp. 235-260. http://dx.doi.org/10.1111/j.1467-646X.2004.00109.x

Lu, C., Liao, G.M. \& Yang, Y.C. (2007). Ownership structure, information disclosure and corporate value: An empirical analysis of Taiwan companies", paper presented at the 13th Asia Pacific Management Conference, Monash University, Melbourne, available at: http://210.70.175.208/dr_bonus/adminpage/paperfile/20071207082044.pdf (accessed 29 April 2008).

Luo, S., Courtenay, S.M. \& Hossain, M. (2006). The effect of voluntary disclosure, ownership structure and proprietary cost on the return-future earnings relation, Pacific-Basin Finance Journal, Vol.14, pp. 501-521. http://dx.doi.org/10.1016/j.pacfin.2006.02.002 
Mak, Y.T. \& Li, Y. (2001). Determinants of corporate ownership and board structure: Evidence from Singapore. Journal of Corporate Finance, 7, 235-256. http://dx.doi.org/10.1016/S0929-1199(01)00021-9

Malaysian Code of Corporate Governance. (2001). Securities Commission, Kuala Lumpur, available at: http://www.ecgi.org/codes/documents/mccg_mar2000.pdf (accessed 30 April 2008).

Malaysian Code of Corporate Governance. (2007). Securities Commission, Kuala Lumpur, available at: http://www.ecgi.org/codes/documents/cg_code_malaysia_2007_en.pdf (accessed 30 April 2008).

Mohammad Rizal, S. (2006). Legal transplantation and local knowledge: Corporate governance in Malaysia, Australian Journal of Corporate Law, Vol. 20 No.10, pp. 1-29.

Muth, M. M. \& Donaldson, L. (1998). Stewardship theory and board structure: a contingency approach", Scholarly Research and Theory Papers, Vol. 6 No.1, pp. 5-28.

Norita, M.N. \& Shamsul Nahar, A. (2004). Voluntary disclosure and corporate governance among financially distressed firms in Malaysia, The Electronic Journal of the Accounting Standards Interest Group of AFAANZ, Vol. 3 No 1, available at: http://www.cbs.curtin.edu.au/files/nasir-abdullah.pdf (accessed 16 May 2008).

Patel, S.A., Balic, A. \& Bwakira, L. (2002). Measuring transparency and disclosure at firm level in emerging market, Emerging Markets Review, Vol 3, pp. 325-337. http://dx.doi.org/10.1016/S1566-0141(02)00040-7

Pramanik, Alok Kumar; Shil, Nikhil Chandra \& Das, Bhagaba.n (2007). Environmental accounting and reporting With special reference to India. Published in: The Cost and Management, Vol. Vol. 35 No. 6, No. November-December 2007 (18. January 2008): pp. 16-28.

Ramzi Benkraiem, (2008). The influence of institutional investors on opportunistic earnings management, International Journal of Accounting, Auditing and Performance Evaluation, Vol. 5, No. 1, pp. 89-106. http://dx.doi.org/10.1504/IJAAPE.2008.020195

Rashidah, A.R. \& Fazilah, T. (2006). The effectiveness of corporate governance mechanisms on capital structure decisions in Malaysia, paper presented at the World Congress of Accounting Educators, Istanbul, Turkey.

Salim, C. (2007). Block-holder ownership, family control and post-listing performance of French IPOs, Managerial Finance, Vol. 33 No.6, 388-400. http://dx.doi.org/10.1108/03074350710748740

Salleh, H.H. \& Mallin, C. (2002). Corporate governance in Bahrain, Corporate Governance, Vol. 10 No.3, pp. 197-210. http://dx.doi.org/10.1111/1467-8683.00284 
Santema, S., Hoekert, M., Rijt, J.V.D. \& Oijen, A.V. (2005). Strategy disclosure in annual reports across Europe: A study on differences between five countries, European Business Review, Vol 17 No.4, pp. 352-366. http://dx.doi.org/10.1108/09555340510607398

Seifert, B., Gonenc, H. \& Wright, J. (2005). The international evidence on performance and equity ownership by insiders, blockholders, and institutions, Journal of Multinational Financial Management, Vol. 15, pp. 171-191. http://dx.doi.org/10.1016/j.mulfin.2004.08.003

Shamsul Nahar, A. (2004). Board composition, CEO duality and performance among Malaysian listed companies, Corporate Governance, Vol. 4 No. 4, pp. 47-61. http://dx.doi.org/10.1108/14720700410558871

Sharifah, B., Bakhtiar, A., Nor Hashimah, J., Noraida, AR. (2008). An investigation of the Association between Corporate Governance and Environmental Reporting in Malaysia, Asian Journal of Business and Accounting, Vol.1 No.2, pp 65-88.

Talha, M., Sallehhuddin, A., \& Mohammad, J. (2006). Changing pattern of competitive disadvantage from disclosing financial information, Managerial Auditing Journal, Vol.21 NO.3, pp. 265-274. http://dx.doi.org/10.1108/02686900610653008

United Nations. (2003). Selected issues in corporate governance: Regional and country experience, paper presented at United Nations Conference on Trade and Development, available at: http://www.unctad.org/en/docs/iteteb20033_en.pdf (accessed 30 April 2008).

Uwalomwa, U. \& Uadiale, O.M. (2011). Corporate Social and Environmental Disclosure in Nigeria: A Comparative Study of the Building Material and Brewery Industry, International Journal of Business and Management, Vol. 6 No. 2.

Williams, D.R., Duncan, W.J., Ginter, P.M. \& Shewchuk, R.M. (2006). Do governance, equity characteristics, and venture capital involvement affect long-term wealth creation in US health care and biotechnology IPOs?, Journal of Health Care Finance, Vol.33 No. 1, pp. 54-71.

Wong, C. (2005, February). The rating agency perspective on corporate governance. Paper presented at Asia Corporate Governance Conference 2005: Managing Corporate Responsibility and Crisis through Fairness, Transparency and Accountability, Kuala Lumpur, Malaysia.

Yatim, Kent, P. \& Clarkson, P. (2006). Governance structures, ethnicity and audit fees of Malaysian listed firms. Managerial Auditing Journal, 21 (7), 757-782. http://dx.doi.org/10.1108/02686900610680530

Yoshikawa, T. \& Phan, P.H. (2003). The performance implications of ownership-driven governance reform, European Management Journal, Vol. 21 No.6, pp. 698-706. http://dx.doi.org/10.1016/j.emj.2003.09.013

Zulkarnain, M.S. (2007, February). Towards better corporate governance and transparency, paper presented at Conference on Managing Knowledge in the Borderless World, Selangor, Malaysia. 


\section{Appendix}

\section{Social and Environmental Disclosure Items in the Annual Reports}

Please give your opinion on how important you think the following items in the annual report are by circling or crossing the appropriate number. The objective is to obtain your opinion on the importance of these items in general, as some of the following items may not be appropriate to your company or organization specifically.

\begin{tabular}{|c|c|c|c|c|c|c|}
\hline No. & Description & & & & & \\
\hline 1 & $\begin{array}{l}\text { Employees' general information } \\
\text { Qualitative information, e.g. share-option policy } \\
\text { Quantitative information, e.g. amount spent on } \\
\text { training }\end{array}$ & & $\begin{array}{l}2 \\
2\end{array}$ & $\begin{array}{l}3 \\
3\end{array}$ & 4 & \\
\hline 2 & $\begin{array}{l}\text { Community service } \\
\text { Qualitative information, e.g. community program } \\
\text { Quantitative information, e.g. charitable donation }\end{array}$ & & & $\begin{array}{l}3 \\
3 \\
\end{array}$ & & \\
\hline 3 & $\begin{array}{l}\text { Environmental disclosure } \\
\text { Qualitative information, e.g. environmental } \\
\text { protection policy } \\
\text { Quantitative information, e.g. effect on environment }\end{array}$ & & $\begin{array}{l}2 \\
2 \\
\end{array}$ & $\begin{array}{l}5 \\
3\end{array}$ & & \\
\hline
\end{tabular}

